\title{
Exploratory opportunities based in seismic and attributes interpretation analysis in Paleogene turbidites sands, South Center Espírito Santo Basin.
}

${ }^{*}$ Rodrigo de Paiva Ferro (Lagemar-DOT/UFF), Cleverson Guisan Silva (Lagemar-DOT/UFF)

Copyright 2019, SBGf - Sociedade Brasileira de Geofísica

This paper was prepared for presentation during the $16^{\text {th }}$ International Congress of the Brazilian Geophysical Society held in Rio de Janeiro, Brazil, 19-22 August 2019.

Contents of this paper were reviewed by the Technical Committee of the $16^{\text {th }}$ International Congress of the Brazilian Geophysical Society and do not necessarily represent any position of the SBGf, its officers or members. Electronic reproduction or storage of any part of this paper for commercial purposes without the written consent of the Brazilian Geophysical Society is prohibited.

\section{Abstract}

The present study represents an exploratory workflow applied to a dataset acquired in the central-south portion of the Espírito Santo Basin, southeast Brazil. This workflow used an industry multidisciplinary practice, following geological, geophysical and petrophysical analysis to better correlate all the data available (2D/3D seismic, well logs, stratigraphic markers and reports for the wells drilled in the area). As part of the study results, two potential exploratory opportunities were identified in the 3D seismic and called Beira Rio and Castelão both of them consisting of possible turbidite sands from the Paleogene, Urucutuca Formation, in structural traps sealed by shales under the influence of salt tectonics.

\section{Introduction}

Situated in the southeastern brazilian margin, the offshore part of Espírito Santo Basin has proximally 115.000 km², reaching up to 3000 meters of water column on the deepest parts. The Vitória high defines the southern limit with Campos Basin and the Abrolhos Volcanic Complex delimits the northern limit with the Mucuri Basin (Vieira et al., 1994).

The Espirito Santo Basin can be described as a mature basin on its onshore portion with proved exploratory history success since the early 70's but in the offshore portion it's still categorized in the exploratory phase with only a limited number of discovered fields. Even though the first finding's in the past, it was only on the late 90's that foreign investments could be made and allowed the discovery of the basin first called deep water gas field (Canapu). Through the continuity of investments in exploratory campaigns with better volumes of seismic and wells drilled, were possible to find the deep waters oil and gas fields of Golfinho and Camarupim from the post salt turbidities reservoirs in the Urucutuca formation which brought more productive reserves and attractiveness for this unexplored part of the basin.

As stated in França et al., (2007), during the Paleogene a new tectonic and sea level change occurs on the Espírito Santo Basin. Consequence to the Serra do Mar uplift and the Abrolhos volcanic activity, increasing the siliciclastic supply from northwest and with the continuous salt tectonic has settled an intense control on the turbidites sands distribution basinwards.

The post salt accumulations on the offshore deeper part of the basin, consists mostly by marine channeled confined turbidities sandstones bodies of the Urucutuca formation sealed by the shales from the same Urucutuca formation in a structural context related to the presence of listric and normal faults due to the gravitational depositional flow and from halokinesis induced process upon the sedimentary column, making it possible to preserve these accumulations close to these salt structures according to Estrela et al., (1984) and Frota (1998).

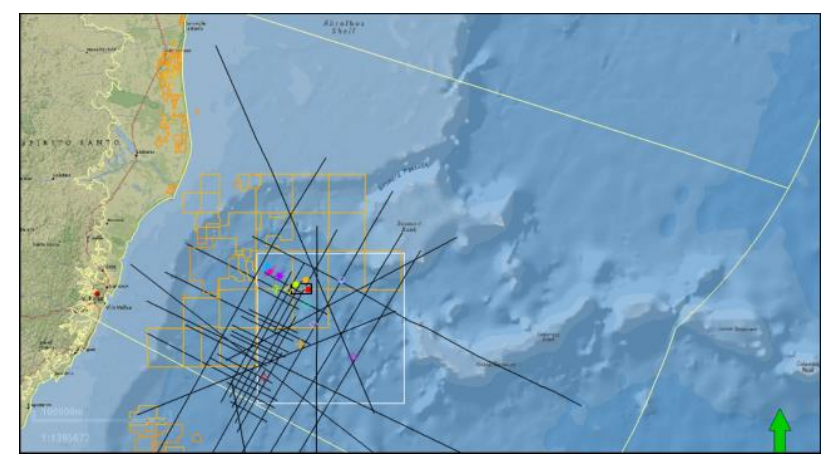

Figure 1 - Espírito Santo Basin location and study area with the dataset (white square).

\section{Method}

The current study has as main objective to present some of the oil and gas workflow stages during the identification of possible exploratory opportunities in the post salt play on the central south portion of the Espírito Santo Basin, through an integrated geological and geophysical analysis on the database available and known exploration fields in the area.

As part of a master's study research the data used in this work was delivered by the National Petroleum Agency (ANP) and its exploration and production database (BDEP) to the Federal Fluminense University postgraduation course in Ocean and Earth Dynamics (DOT). The dataset contained one seismic volume, thirty 2D seismic lines, (all in time domain) and fifteen wells on the area.

An initial part of the data control after loading for interpretation purpose is to confirm if all the seismic are represented in a standard polarity and phase that allow the interpreter to better correlate geological events and anomalies. For the wells, the analysis comprises in verify the existence and removal of inconsistent data (spikes) 
correlated to noise that would damage the correlation with the seismic and geological data.

The seismic and well integration occurs with the construction of the synthetic seismogram, originated through calculations from the sonic and density log curves to estimate the reflection coefficients representative for the geologic interfaces and convolution with a seismic wavelet. This synthetic seismogram corresponds to the modeling of these responses obtained from the well logs and how would it be represented in seismic amplitude. Once these seismic and wells are tied, the geological interpretation can start with better confidence.

After the interpretation finishes, other important part of the study, the velocity model creation allows to take the seismic and interpretation data from time to depth domain using as control points the well stratigraphic markers. Since this model is only an approximation of the velocities based upon the interpretation, wells available and the knowledge of the interpreter on the surrounding geology, it contains uncertainties present in all conversion methods and eventually reflected on the converted data. These distortions may appear like pull-up or pull-down in areas close to salt bodies due to its great variation in velocities or just in a vertical wrong placement of the events requiring the interpreter review the wells control points and his geological understanding of the area.

Supporting the seismic interpretation and concurrently the results obtained from the depth conversion the use of seismic attributes was shown of greatly assistance in this study. Chopra and Marfurt (2007) describe attributes as being a quantitative measure of a seismic property and in this work the use of geometric and energy attributes were useful not only in the detection of interruptions on the seismic trace, commonly associated with faults, but in identifying variations in the seismic trace intensity, which could be related to lateral changes in the facies. The usage of seismic attributes reveals its importance once enhances the stratigraphic and structural geologic features hidden on the seismic data.

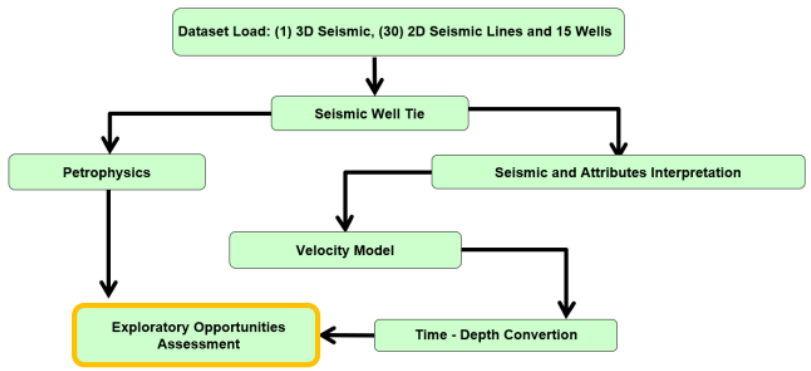

Figure 2 - Workflow of activities applied on the study.

\section{Results}

Since the dataset available for this study holds both $2 \mathrm{D}$ and 3D seismic data it was possible to analyze a large area of coverage that allowed to create structural, isopach's and attribute surface maps in depth to verify how intense was the influence of the salt tectonics in the Paleogene sediments. Combined with the assistance provided by the attributes applied on the data to detect the possible exploratory opportunities.

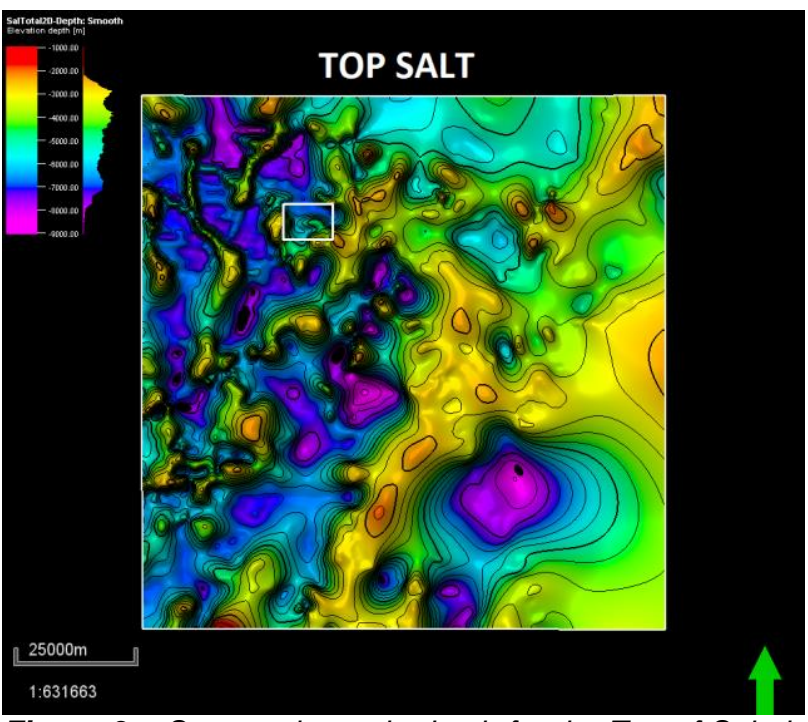

Figure 3 - Structural map in depth for the Top of Salt, in the white square the $3 D$ seismic area.

The top of salt structural surface reveals the presence of regions of occurrence of extent salt diapirs, mini basins and salt walls, with a preferential direction NE-SW to N-S, being identify to distinct domains. The first one, on the center west portion, the diapirs show a narrow geometry and surrounded by mini basins, while on the center east and consequently the deeper part of the basin there's a predominance of the salt walls and salt canopies.

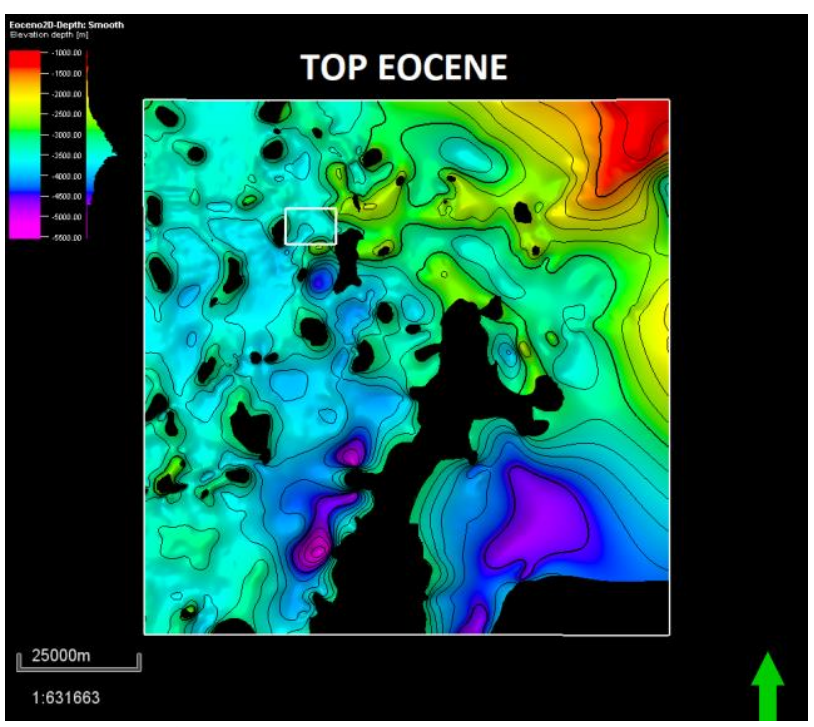

Figure 4-Structural map in depth for the Top of Eocene, in white square the $3 D$ seismic area.

The Eocene structural surface shows a continuous impact of salt diapirs sectioning the sedimentation and influencing in sedimentary routes associated alongside the salt bodies, consequently the presence of faults is common on these areas. 


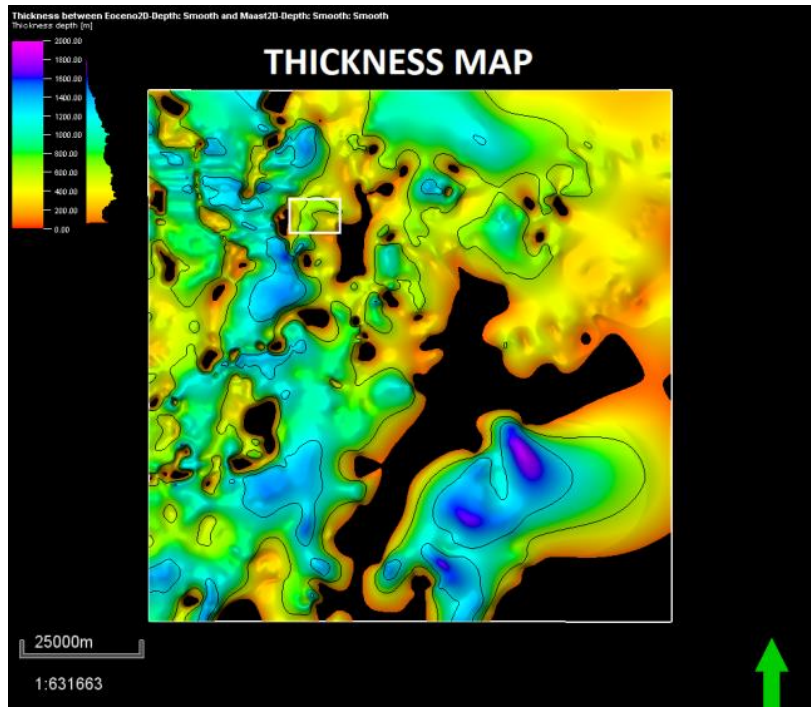

Figure 5 - Thickness map between the Eocene and Maastrichtian, in white square the $3 D$ seismic area.

Although was in the thickness map of Eocene that was exposed the sediment thickness not only in local depocenters associated to the salt tectonics but its continuity in a wilder area, revealing the change in the basin tectonic context with the occurrence of Abrolhos volcanic complex and the basin border uplift.

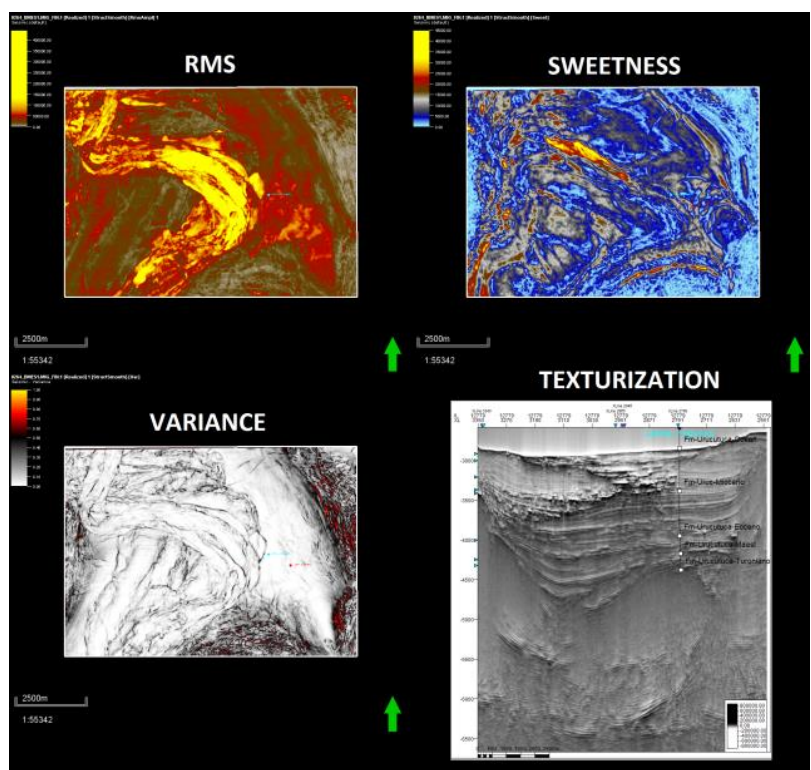

Figure 6 - Seismic attributes applied on the data to highlight geological features.

The use of attributes like RMS (root mean square) to highlight geologic features like channels, Sweetness for areas of low frequency signal, Variance, to analyze the signal similarity between traces for faulted areas and texturization to highlight the difference between seismic interfaces, like an outcrop analysis, were of great assistance in this work and definition of the exploratory opportunities.

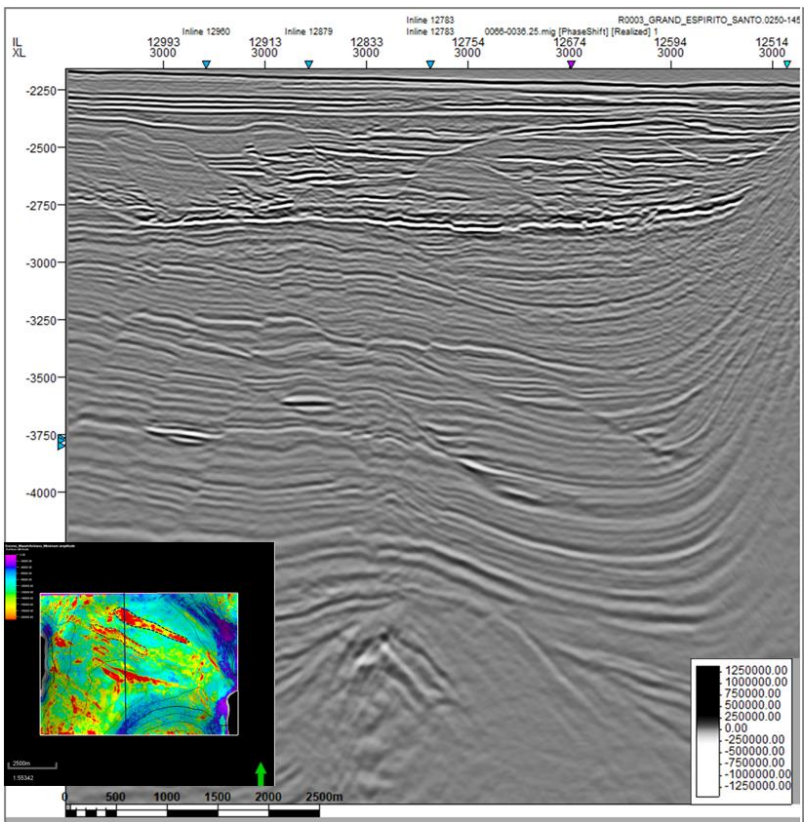

Figure 7 - Crossline section in depth with minimum amplitude attribute map on bottom left.

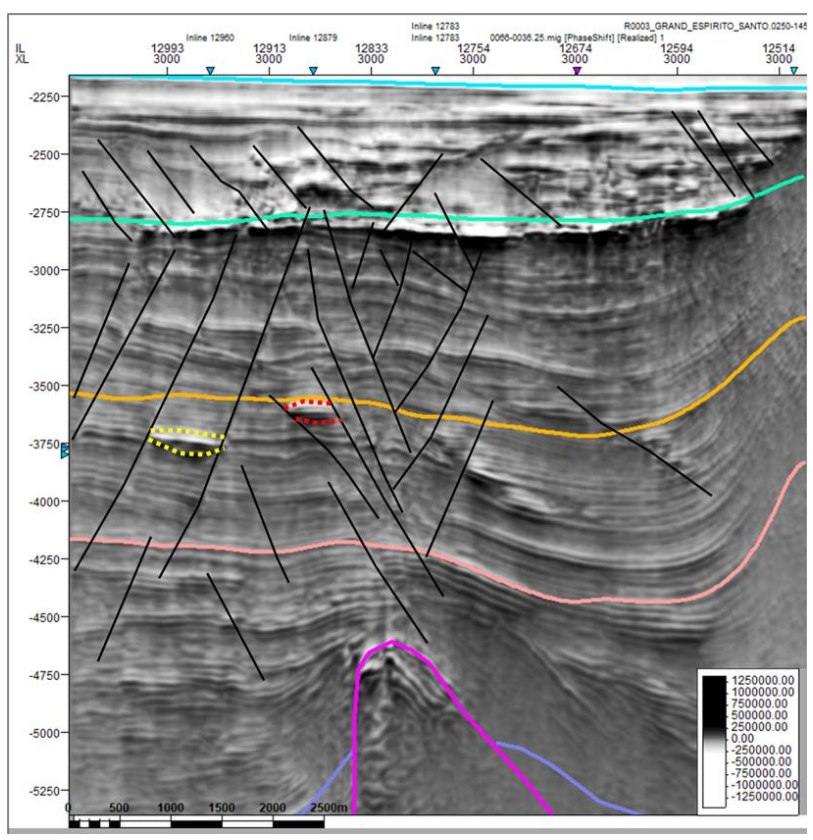

Figure 8-Crossline section in depth with interpretation: Ocean floor (blue), Miocene (green), Eocene (orange), Maastrichtian (light pink), Turonian (purple) Salt (magenta) faults (black) and the exploratory opportunities (red and yellow dots). 


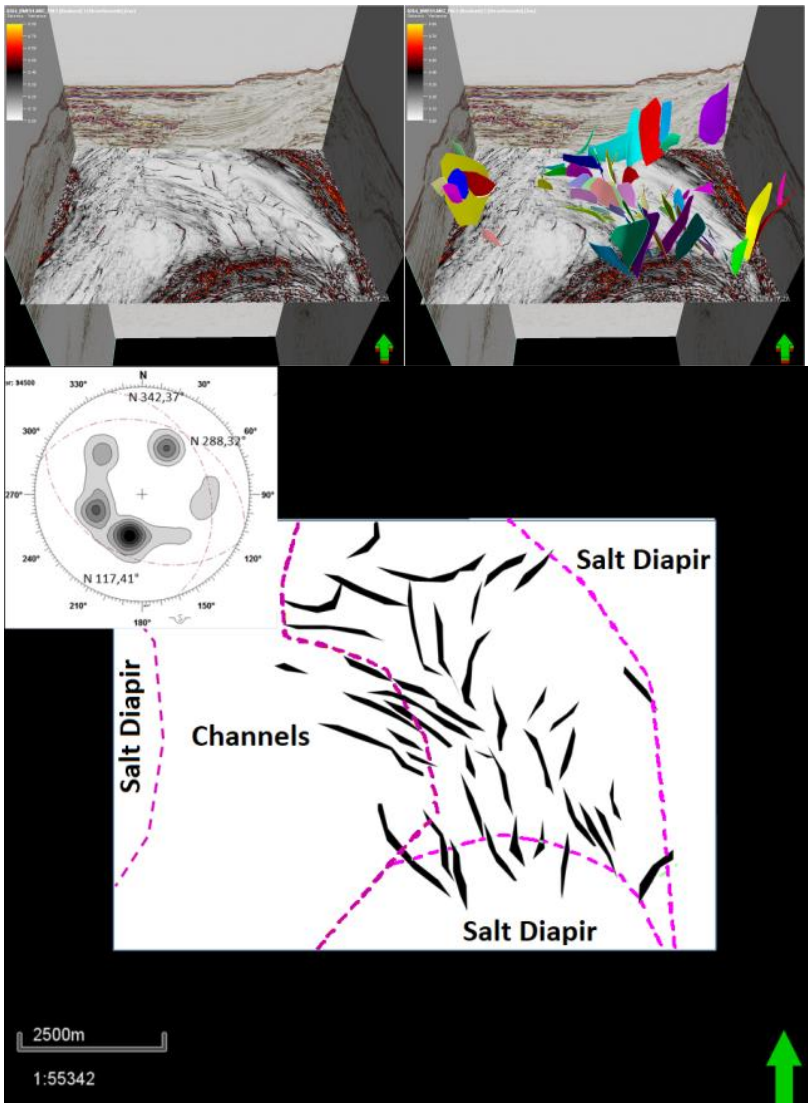

Figure 9 - Seismic attribute (variance) in depth slice, applied on the data to assist in faults interpretation.

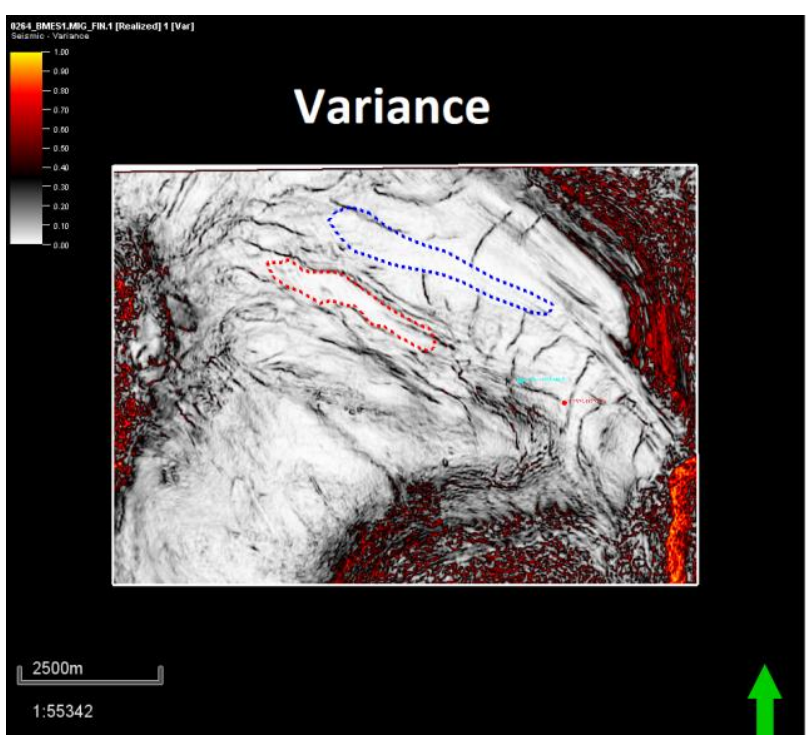

Figure 10 - Seismic attribute (variance) in depth slice, applied on the data to highlight geological features. Exploratory opportunities Beira Rio in blue and Castelão in red.

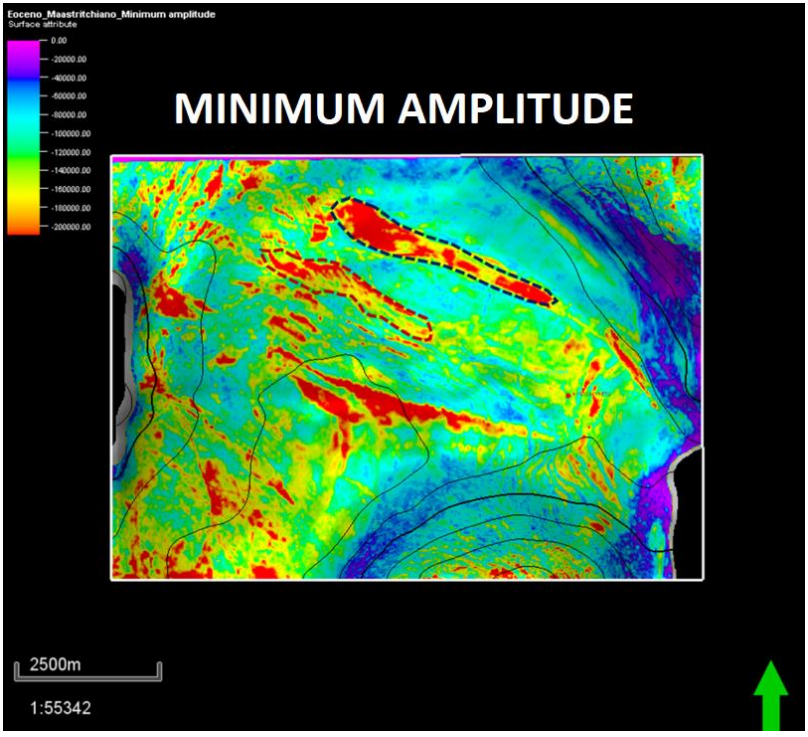

Figure 11 - Seismic attribute (minimum amplitude) in depth slice, applied on the data to highlight geological features with exploratory opportunities Beira Rio in blue and Castelão in red.

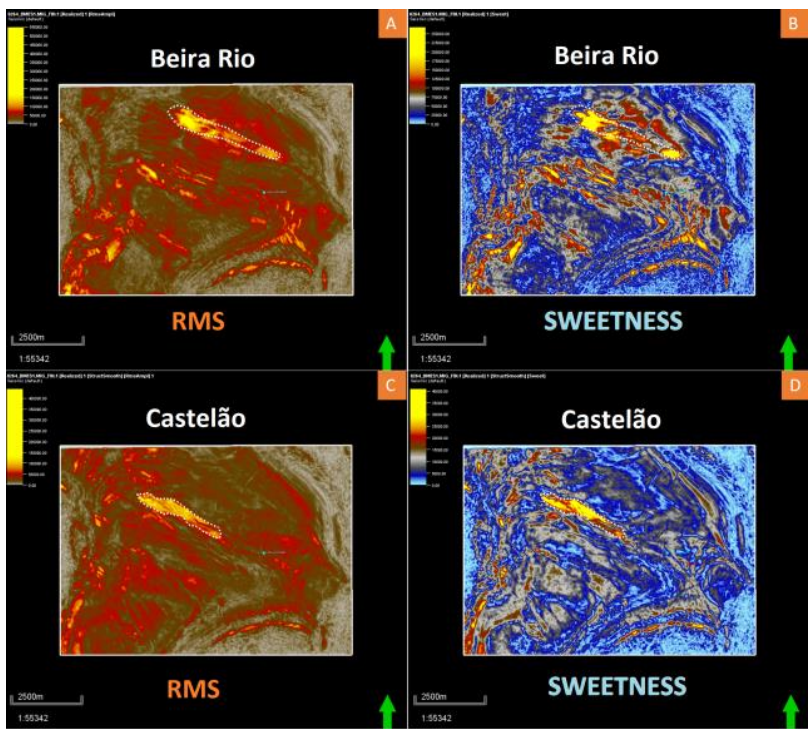

Figure 12 - Seismic attributes in depth slice, applied on the data to highlight geological features.

Most of the faults mapped on the interval between the Maastrichtian and Miocene could be classified as normal faults and associated to the salt tectonics. The stereogram analysis revealed that locally most faults are NW-SE although a rotation tendency demonstrates faults with a N-S to NE-SW with dip to SE related to the basin depocenter.

For the exploratory opportunities, the combination of the attributes available and the interpretation analysis made it possible to define two possible opportunities called Beira Rio and Castelão on the 3D seismic.

Defined as NW-SE Paleogene channeled structures delimited by faults, these opportunities are related to the salt tectonic and its influence in the petroleum system on these potential reservoirs in a structural trap scenario. 


\section{Conclusions}

The hydrocarbon exploration in Espírito Santo offshore Basin shows a history of association with salt tectonic process with most discoveries occurring in structural or stratigraphic traps related to salt diapirs or rafts structures due to salt movement.

In the study area two possible exploratory opportunities Beira Rio e Castelão, were identified in channeled Paleogene structures in the post salt Urucutuca formation.

With the use of seismic attributes and interpretation techniques inside the 3D seismic area, were possible to delimit and analyze its amplitude response and extension. The Beira Rio opportunity shows an area of $1.62 \mathrm{~km}^{2}$ in an average depth of $3700 \mathrm{~m}$ and thickness up to 120 meters. The Castelão opportunity presents a bigger area, approximately $2.12 \mathrm{~km}^{2}$, depth of $3600 \mathrm{~m}$ and thickness around 105 meters. Both of them after the attribute analysis and interpretation, present indicators of structural trap components sealed by shales.

To better evaluate these exploratory opportunities is recommended due to complex geologic features created by the halokinesis and tectonic events, use of PSTM (prestack time migration) data to improve seismic resolution to enhance structures imaging and in consequence refinement of the interpretation reducing the risks.

Although the geological complex structures present on the area of study, the results obtained revealed the exploratory potential to be developed in the offshore portion of the Espírito Santo Basin.

\section{Acknowledgments}

I would like to thanks the Federal Fluminense University through the Post-Graduation course in Ocean and Earth Dynamics (DOT) and Prof. Dr. Cleverson Guisan Silva, for the opportunity to develop this work as part of my Master degree. Also, would like to thanks the National Petroleum Agency (ANP) and its exploration and production database (BDEP) for the data used, and Schlumberger for the academic software license.

\section{References}

ANP 2015. Bacia do Espírito Santo. Sumário Geológico e Setores em Oferta. Superintendência de Definição de Blocos. Ronan Ávila.

BULHÕES, E. M.; AMORIM, W, N. Princípio da Sismocamada Elementar e sua aplicação à Técnica Volume de Amplitudes (TecVA). In: Congresso Internacional Da Sociedade Brasileira De Geofísica, 9. 2005, Salvador, Bahia. Artigo. Rio de Janeiro: SBGF, 2005. p. 1-6.

CHOPRA, S., MARFURT. K. J. 2007. Seismic Attributes for Prospect Identification and Reservoir Characterization. SEG - Geophysical Developments series n.11

ESTRELlA, G., MELlO, M.R., GAGLIANONE, P. C., AZEVEDO, R.L.M., TSUBONE, K., ROSSETTI, E.,
CONCHA, J. E. BRÜNING, I.M.R.A. 1984, "The Espírito Santo Basin (Brazil) source rock characterization and petroleum habitat". In: American Association of Petroleum Geologists Bulletin. Petroleum geochemistry and Basin evaluation. Tulsa, pp. 253-271 (AAPG Memoir n. 35).

FOSSEN, H. 2012. Geologia Estrutural. Tradução: Andrade. F. R. D., Oficina de Textos, São Paulo, SP

FRANÇA, R. L.; DEL REY, A. C.; TAGLIARI, C. V.; BRANDÃO, J. R.; FONTANELLI, P. R. 2007. Bacia do Espírito Santo. Boletim Geociências da Petrobras, Rio de Janeiro, v. 15, n.2, p. 501 - 509, maio/nov.

FROTA, E.S.T., 1998, "Geochemical characterization and classification of oils from the Espírito Santo Basin (Brazil) using principal components analysis": 6th Latin American Congress on Organic Geochemistry, Isla Margarita, Venezuela, CD-Rom Abstracts

MOHRIAK, W.U., SZATMARI, P., ANJOS, S.M.C. 2008. Sal: Geologia e Tectônica. Exemplos nas Bacias Brasileiras. Primeira edição. Editora Beca.

VIEIRA, R.A.B., MENDES, M.P., VIEIRA, P.E., COSTA, L.A.R., TAGLIARI, C.V., BACELAR, A.P., e FEIJÓ, F.J. 1994. Bacias do Espírito Santo e Mucuri. Boletim de Geociências da Petrobrás. 8(1), 191-202. 